OPEN ACCESS

International Journal of Advanced Economics

P-ISSN: 2707-2134, E-ISSN: 2707-2142

Volume 3, Issue 1, P.No. 1-9, April, 2021

DOI: 10.51594/ijae.v3i1.213

Fair East Publishers

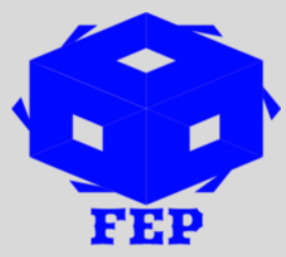

Journal Homepage: www.fepbl.com/index.php/ijae

\title{
EXAMINING THE KEY SUCCESS FACTORS IN AFRICA \\ BASED ON 3 ASPECTS: ADAPTATION, EFFICIENCY AND STRATEGIC POSITIONING FROM A SURVEY ON ENTREPRENEURS IN BURKINA FASO
}

\author{
Nicolas Carbonell ${ }^{1}$, Dr. Théophile Bindeouè Nassè ${ }^{2,3}$ Dr. Mahamadi Nanéma ${ }^{4}$ \\ ${ }^{1}$ Universitat Politecnica de Catalunya, Barcelona (Spain) \\ ${ }^{2}$ University of Business and Integrated Development Studies, Wa (Ghana) \\ ${ }^{3}$ Thomas Sankara University, (Burkina Faso) \\ ${ }^{4}$ Norbert Zongo University, Koudougou, Burkina Faso
}

*Corresponding Author: Dr. Théophile Bindeouè Nassè ${ }^{2}$

Corresponding Author Email: nassetheophile2009@gmail.com

Article Received: 13-03-20

Accepted: $31-03-21$

Published: 15-04-21

Licensing Details: The author retains the right to this article. The article is distributed under the terms of the Creative Commons License (http://www.creativecommons.org/licences/by-nc/4.0/) which permits non-commercial use, reproduction, and distribution of the work without further permission provided the original work is attributed as specified on the Journal open access page.

\begin{abstract}
The main purpose of this paper is to examine the different types of factors in the African business context and in particular in the context of Burkina Faso, that can help companies to be successful. It is about the identification of the key successful factor among some main factors such as adaptation, efficiency and strategic positioning

The data is from a survey on entrepreneurs in Burkina Faso, who attended the Africallia business meeting in 2018. The results show that the adaptation to the context is one of the main factors for business success. Thus, the suggestion is that companies should adapt to the African context in order to improve their profit, performance and thus gain a tremendous success.
\end{abstract}

Keywords: Success Factors, Business, Companies, Adaptation, Efficiency, Strategic Positioning, Africa.

\section{INTRODUCTION}

Companies that are operating in the African context face many challenges that sometimes affect their success, both at their national level but also at the international level. The present research on business success factors is based on the work developed by Porter (1991) arguing that business success depends on various factors particularly those that are external to the company. 
A research on African companies' recruitment methods and management practices by Carbonell et al. (2020) has shown that the companies in the context are using traditional methods and disregarding the modern methods of recruitment. Another contribution by Livian and Shamba (2014) also shows that management practices in the African context are still in an old-style framework and that there is to mix it with Western management practices. In the same line Nasse (2016) has shown that African companies need a hybridization of management practices to the within the context by adapting the Western management theories into the context.

Till now, no research has tried to make a comparison between adaptation, efficiency and strategic positioning in order to find out the best factor that really suits with the African companies' success. Thus, the present study is seeking to establish such a comparison and to bring out some recommendations for managers.

The main objective of this research is to determine the main factor that fosters companies' success among the following factors: adaptation, efficiency and strategic positioning.

\section{LITERATURE REVIEW}

\section{Concepts}

The literature review will allow the definition of the key concepts:

Adaptation to Africa: The concept of adaptation has been viewed by Livian and Shamba (2014) as the fact of adjusting western management theories to the African context what seems to be a hybridization of management theories. It is also a process of change management by which a company becomes better suited to a particular business environment or business context (Nasse, 2016). For its part, Adaptation to Africa is influenced by the characteristic aspects of African culture, and in particular our case study which is Burkina Faso.

Organizational Efficiency: This concept is related to all the modern management practices, and particularly to human resources management. At a technical level it could be focused to the obtention of the highest possible outputs with the least possible inputs. But according to Williamson (1999) an efficient organization implies that there is no other possible alternative allowing to realize more net gains.

Strategic Positioning: The concept is concerned with the way in which a business as a whole distinguishes itself in a valuable way from its competitors and delivers value to specific customer segments (Wickham, 2001: 230). Strategic positioning (organizational behaviour towards the market) is to the company what the personality is to the individual. For Porter (1996), strategic positioning is about the controllable comparative advantage of a given company as compared to its competitors.

\section{Success Factors and Management in the African Context}

The least developed countries of Africa are where it is usual to confuse the company with the employer's assets, (Weber, 2018), the employees with the extended family (Carbonell, 2020), and where corruption is present (Akouwerabou, 2018) to distort both the supply and demand rules, it is not possible to analyse the success of an African company based on the same factors as in the developed world (Kamdem et al. 2020).

Success Factors have been defined by Rockhart (1979), but popularized by Porter (1991), diamond model. We take also in account the HRV growth determinants modelled by Rodrik, Haussman and Velasco (2005) and the Pestel graph, and we assume that the key success factors we have to study are Strategic Positioning, Efficiency and Adaptation to Burkina Faso, as we present in the following table: 
Table 1

Analysis Grid of the Key Success Factors for the African Enterprises

\begin{tabular}{llll} 
ONION MODEL & PROBLEMS & SOLUTIONS & KEY SUCCESS FACTORS \\
\hline ENTERPRISE IDENTITY & $\begin{array}{l}\text { Absence of entry } \\
\text { barriers. Opportunism }\end{array}$ & $\begin{array}{l}\text { Competitive } \\
\text { intelligence }\end{array}$ & Strategic positioning \\
\hline $\begin{array}{l}\text { ENTERPRISE } \\
\text { MANAGEMENT }\end{array}$ & $\begin{array}{l}\text { Expensive and limited } \\
\text { financing. } \\
\text { infrastructures }\end{array}$ & $\begin{array}{l}\text { Modern } \\
\text { Panagement }\end{array}$ & Organizational efficiency \\
\hline $\begin{array}{l}\text { BUSINESS } \\
\text { ENVIRONMENT }\end{array}$ & $\begin{array}{l}\text { Corruption and market } \\
\text { barriers. African } \\
\text { resources management }\end{array}$ & Adaptation to Africa \\
\hline
\end{tabular}

Source: Fieldwork, 2018

Based on Hampel-Milagrosa et al. (2015) onion model, we see a 3 skins model from core (enterprise identity) to external skin (environment), at each level different problems meet generic solutions and key success factors. In our onion model, we focus on identifying the relevance of 3 key success factors that influence business success and their correlation with the economic sector and the level of sales of the enterprises of Burkina Faso. The first key success factor we define is strategic positioning and corresponds to enterprise identity (and differentiation from competitors), the core of the onion. Secondly, organizational efficiency is the key success factor related to enterprise management characteristics, our intermediate onion skin. And finally, adaptation to Africa is the key success factor linked to the business environment, the external skin of the onion (concerned by competitors' rivalry, economic policy and corruption, partners and local human resources behaviors).

\section{Adaptation Theory}

According to the adaptation theory businesses or companies will adjust how they operate or how they function in term of management, in an effort to keep up with the challenging and changing market conditions, shifting environment factors or competition. The theory of adaption is assumed by some authors such as Levinthal (1997), Ansari, Fiss, and Zajac (2010), Livian and Shamba (2014), Nasse (2016), Eggers and Park (2018), Aldrich, Ruef, and Lippmann (2020).

Research Hypothesis: Among the 3 Key Success Factors of African enterprises, the factor "Adaptation to environment" is the most important for African entrepreneurs.

It indicates that there are African management rules that everybody has to understand before to start a business in this continent. To test this hypothesis, we start from the categorization of our sample of interviewed entrepreneurs. Being able to build results referring to the sector in which they develop economically and the turnover they handle annually.

\section{METHODOLOGY}

A survey was carried out among the participants of the Africallia 2018 Forum, obtaining 114 valid results from businessmen from Burkina Faso. This survey examined many affirmations (corresponding to the $3 \mathrm{key}$ success factors) relatives to the management behaviour in their 
business. In addition, information was obtained on the sectors in which they are located, as well as on turnover and socio-demographic variables (sex and age).

The different sectors of activity surveyed were identified and grouped into 4; agriculturalindustrial, construction, commerce and services. Likewise, the turnover expressed by the entrepreneurs was broken down into 5 brackets from which to choose; 0 - 19 million, 20 to 50 million, 51 to 500 million, 501 million to 3 billion and more than 3 billion. This stratification made it possible to identify small, medium and large companies.

Measuring Tool: The measure of this study was to exploit the advantages of carrying out a survey (Linares Fontela, 2003), namely precision, the possibility of classification and obtaining valuable conclusions. It was based on the conduct of a personal survey, asking 34 questions in which socio-demographic data such as; age, sex, country of origin. Then, questions are asked about the characteristics of the company; legal form, position in the company, turnover, sector of economic development, etc. To measure key success factors, related statements were measured using a 9-point Likert scale. All of the statements have been broken down and categorized according to the key success factors considered in this research.

Investigation Process: This exploratory study used statistical solutions of IBM-SPSS products and services for the analysis of data obtained from the surveys. The sample size was made from the 441 participants at the Africallia 2016 congress, who with 114 respondents reached the maximum error of $97 \%$ or $9.25 \%$ (Ganassali, 2009; Hejase \& Hejase, 2013).

Sample Description: The overall sample of the surveyed (see table 2) is 114 entrepreneurs who attended the Africallia 2018 business event in the capital city of Ouagadougou.

Ethical Issues: The respondents answer to the questions without any need to reveal their identity. The data gathered from them is for purpose of the present research (Nassè, 2020).

Table 2

Sample Characteristics

\begin{tabular}{lccc}
\hline Vemale & Frequency & Percent & Accumulated percent \\
\hline Male & 24 & 21.1 & 21.1 \\
\hline Total & 90 & 78.9 & 100.0 \\
\hline $\mathbf{2 5 - 3 5}$ & 114 & 100.0 & \\
\hline $\mathbf{3 6 - 4 5}$ & 28 & 24.6 & 24.6 \\
\hline $\mathbf{4 6 - 5 5}$ & 57 & 50.0 & 74.6 \\
\hline $\mathbf{5 6}$ and above & 28 & 24.6 & 99.2 \\
\hline Total & 1 & 0.8 & 100.0 \\
\hline Agricultural-Industrial & 114 & 100.0 & 20.2 \\
\hline BTP & 23 & 20.2 & 29.8 \\
\hline Commerce & 11 & 9.6 & 53.5 \\
\hline Services & 27 & 23.7 & 100.0 \\
\hline Total & 53 & 46.5 & 25.4 \\
\hline 0 -19 million & 114 & 100.0 & 54.4 \\
\hline $\mathbf{2 0}-\mathbf{5 0}$ million & 29 & 25.4 & 65.8 \\
\hline 51 $-\mathbf{5 0 0}$ million & 33 & 28.9 & 93.0 \\
\hline 501 -3000 million & 13 & 11.4 & 100.0 \\
\hline More than 3000 million & 31 & 27.2 & \\
\hline Total & 8 & 7.0 & \\
\hline
\end{tabular}

Source: Fieldwork, 2018 


\section{RESULTS}

Table 3

Results by Economic Sector

\begin{tabular}{lccc}
\hline & Adaptation to Africa & Efficiency & Strategic Positioning \\
\hline Agricultural-Industrial & 7.36 & 6.48 & 6.10 \\
\hline Construction & 7.01 & 7.50 & 6.10 \\
\hline Commerce & 7.08 & 6.81 & 6.43 \\
\hline Services & 7.33 & 6.85 & 5.98 \\
\hline \multicolumn{4}{c}{ Source: Fieldwork, 2018 }
\end{tabular}

For categorization by sectors, the key success factor with the greatest value is adaptation to Africa, highlighting the agricultural-industrial sector, followed by the service sector. Efficiency is the second assessment, where the service sector stands out by its preference, followed by trade, agricultural-industrial y and construction. Finally, strategic positioning is one of the least valued aspects by sector. Here it is the commerce sector where this key success factor prevails, followed by agricultural-industrial sector.

Table 4

Results by Turnover

\begin{tabular}{cccc}
\hline & Adaptation to Africa & Efficiency & Strategic Positioning \\
\hline 0 - 19 million & 7.59 & 6.03 & 5.31 \\
\hline $\mathbf{2 0}$ - 50 million & 7.44 & 6.47 & 5.84 \\
\hline $\mathbf{5 1}$ - 500 million & 6.74 & 7.15 & 6.48 \\
\hline $\mathbf{5 0 1}$ - 3 billion & 7.55 & 7.53 & 6.78 \\
\hline More than 3 billion & 6.65 & 8.62 & 7.39 \\
\hline & Source: Fieldwork, 2018
\end{tabular}

For the categorization by turnover, Adaptation to Africa is always the most valued key success factor, for entrepreneurs who manage turnover of less than 50 million XOF. On the other hand, Efficiency becomes the first key success factor for companies over 51 million XOF and adaptation to Africa becomes the least valuated key success factor for companies over 3 billion $\mathrm{XOF}$

\section{DISCUSSION}

Previous research in the same context have shown that the eradication of corruption is the the key success factors for African companies (Bako \& Akouwerabou, 2014). For some other authors the eradication of insane business practices and the eradication of fraud are some key factors for success (Nacoulma, Akouwerabou, \& Nassè, 2020; Nassè, 2016).

According to some authors it is rather the management methods that should undergo through a hybridization process for companies to get a full success (Illa, 2012; Shamba \& Livian, 2014; Nassè, 2019). Recent research also has shown that the recruitment methods are very traditional, and they do not help towards the companies' economic growth (Carbonell et al. 2020).

However, these authors explain that when companies grow, they replace traditional recruitment methods by modern ones, which leads to better economic results. These findings are coherent with ours, as optimal human resources management is a part of organizational efficiency. 
Nevertheless, it is found in this research that it is rather the environmental adaptation (to the African context) that is the main key success factor for enterprises.

\section{CONCLUSION}

This research enriches the management literature by adding facts and arguments to improve business behaviour in Africa, showing the importance of the 3 key success factors analysed: environment adaptation, organizational efficiency and strategic positioning. The companies face hard competition, unfair practices (Nassè, 2016) as well as the challenge to apply Western management theories in the context of Africa (Livian and Shamba, 2014). We find that environment adaptation is the most important success factor in Africa, in all economic sectors, although this importance decreases strongly with the size of the enterprises. That could mean that starting a business has to be strongly adapted to Africa but, arrived at a critical size, key success factors for competition have to be under Western World standards.

\section{Acknowledgements}

The research team would like to thank all the companies for their responses to the questionnaire. The team is also grateful to the associate editor of Fair East Publishers Dr. Théophile Bindeouè Nassè for his steady support.

\section{Conflicts of Interest}

The researchers have declared no conflicts of interest.

\section{Funding}

This research has received no financial support.

\section{References}

Abdul-Latif M., Boateng F., \& Eneizan, B. (2019). Success and relevance of social networking sites (SNS) integration in E-recruitment: HR personnel perspectives in Ghana. International Journal of Academic Information Systems Research, 3(8), 12-19.

Adenugba, A. A., Fadoju, O., \& Akhuetie, R. E. (2017). Non-meritocratic factors and the recruitment process in Oyo State Civil Service, Nigeria. African Sociological Review, 21(2), 115-133.

Aldrich, H. E., Ruef, M., \& Lippmann, S. (2020). Organizations Evolving (3 ${ }^{\text {rd }}$ ed.). Edward Elgar Publishing.

Alles, M. A. (2000). Strategic Management Of Human Resources Management By Competencies ( $1^{\text {st }}$ ed.). Argentina, AR: Ediciones Granica.

Anakwe, U. P. (2002). Human resource management practices in Nigeria: Challenges and insights. International Journal of Human Resource Management, 13(7), 1042-1059. https://doi.org/10.1080/09585190210131285.

Ansari, S. M., Fiss, P. C., \& Zajac, E. J. (2010). Made to fit: how practices vary as they diffuse. Academy of Management Review, 35(1), 67-92.

Bretones, F. D., \& Rodríguez, A. (2008). Recruitment and selection of personnel and reception. In M. A mañas y a. slim, human resources. Madrid, MA: Pyramid.

Carbonell, N., Nassè, T. B., Briceno M., J., \& Ouédraogo, A. (2020). Rethinking recruitment methods in Africa for a better management: an evidence from businesses in Burkina Faso. International Journal of Social Sciences Perspectives, 7(2), 81-88. https://doi.org/https://doi.org/10.33094/7.2017.2020.72.81.88

Chiavenato, I. (2000). Human Resource Administration. Colombia, CO: Edit.Mc Graw Hill.

Clark, T., Gospel, H., \& Montgomery, J. (1999). Running on the spot? A review of twenty years of research on the management of human resources in comparative and international 
perspective. International Journal of Human Resource Management, 10(3), 520544.https://doi.org/10.1080/095851999340477.

Cohen, B. (1981). How to select our staff. Mexico, ME: Edit. Limousine.

Cortina, J. M. (1993). What is coefficient alpha? An examination of theory and applications. Journal of Applied Psychology, 78, 98-104.

Cronbach, L. J. (1951). Coefficient alpha and the internal structure of tests. Psychometrika, 16, 297-334.

Dolan, S. L., Valle, R., Jackson, S. E., \& Schuler, R. S. (2007). The management of human resources. Madrid, MA: Mac Graw Hill.

Eggers, J. P., \& Park, K. F. (2018). Incumbent adaptation to technological change: the past, present, and future of research on heterogeneous incumbent response. Academy of Management Annals, 12(1), 357-389.

Ekwoaba, J. O., Ikeije, U. U., \& Ufoma, N. (2015). The impact of recruitment and selection criteria on organizational performance. Global Journal of Human Resource Management, 3(2), 22-33.

Ganassali, S. (2009). Questionnaire surveys with sphinx. Paris, PA: Pearson Education. In Nassè, T. B., Ouédraogo, A. \& Sall, F. D. (2019). Religiosity and consumer behaviour in developing countries: an exploratory study on Muslims in the context of Burkina Faso. African Journal of Business Management, 13(4), 116-127.

Ghebregiorgis, F., \& Karsten, L. (2006). Human resource management practices in Eritrea: Challenges and prospect. Employee Relations, 28(2), 144-163.

Gomez-Mejía, L. R., Balkin, D., \& Cardy, R. (2016). Human resources management. Madrid Spain: Pearson Education.

Hampel-Milagrosa A., Loewe M., Reeg C., (2015) The Entrepreneur Makes a Difference: Evidence on MSE Upgrading Factors from Egypt, India, and the Philippines. World Development, 66(1), 118-130

Hejase, A. J., \& Hejase, H. J. (2013). Research methods, a practical approach for business students (2nd ed.). Philadelphia, PH: Masadir Inc. In Nassè, T. B., Ouédraogo, A. \& Sall, F. D. (2019). Religiosity and consumer behaviour in developing countries: an exploratory study on Muslims in the context of Burkina Faso. African Journal of Business Management, 13(4), 116-127.

Huselid, M. A. (1995). The impact of human resource management practices on turnover, productivity, and corporate financial performance. Academy of Management Journal, $38(3), 635-872$.

Illa H. (2012). Etude des styles de management au Burkina Faso et au Sénégal: Thèse Doctorale. Groningen,GR: Faculté d'Économie de Groningen.

Kamdem, E, Chevalier F., \& Payaud M. A. (2020). La recherche enracinée en management: contextes nouveaux et perspectives nouvelles en Afrique. Caen, CA: Editions EMS.

Kamoche, K. (2001). Understanding human resource management. Buckingham: Open University Press.

Kamoche, K. (2002). Introduction: human resource management in Africa. The International Journal of Human Resource Management, 13(7), 993-997.Available at: https://doi.org/10.1080/09585190210131258

Kanyemba, M., Iwu, C. G., \& Allen-Ile, C. O. (2015). Impact of recruitment and selection on organizational productivity. Evidence from staff of a university in South Africa. Corporate Ownership and Control, 12(2), 177-185.

Karsten, L., \& Pennink, B. J. W. (2007). Total quality management in the African business community of Burkina Faso: A change in perspective on knowledge development. Groningen, GR: CDS Research Report No. 25 ISSN 1385-9218.

Levinthal, D. A. (1997). Adaptation on rugged landscapes. Management Science, 43(7), 934950. 
Linares Fontela, J. (2003). Herramienta 10 - Guía para diseñar encuestas. En B. Branch, \& J. Klaehn, El logro del equilibrio de las microfinanzas (págs. 327-336). Washington, WA: Pact Publications.

Montes, A. M. J., \& González, R. P. (2010). Personnel selection: The search for the right candidate. Vigo, VI: Own Ideas.

Nacoulma, L., Akouwerabou, L., \& Nassè, T. B. (2020). The growing issue of business fraud in Burkina Faso: what best prevention device? International Journal of Management \& Entrepreneurship Research, 2(7), 437-457. https://doi.org/10.51594/ijmer.v2i7.185

Nassè, T. B. (2020). Investigating religious beliefs, consumption and interreligious dissimilarities and similarities in low income countries: a mixed research with reference to Traditionalist, Christian and Muslim consumers in Burkina Faso. International Journal of Social Sciences Perspectives, 7(2), 71-80.

https://doi.org/https://doi.org/10.33094/7.2017.2020.72.71.80.

Nassè, T. B. (2019). Internal equity and customer relationship management in developing countries: A quantitative and a comparative study of three private companies in Burkina Faso. African Journal of Business Management, 13(1), 37-47.

Nassè, T. B. (2019). Internal equity as a factor of companies' economic profitability: A comparative study of three private companies in Burkina Faso through a qualitative approach. Saarbrucken, SA: Lamber Academic Publishing.

Nassè., T. B., \& Sawadogo, Y. M. (2019). Internal equity and customer relationship management in subsistence markets: A comparative and a qualitative study of three private companies in Burkina Faso. International Journal of Management \& Entrepreneurship Research, 1(1), 42-58. https://doi.org/10.51594/ijmer.v1i1.5

Nassè, B. T. (2016). L'équité interne dans la gestion de la relation client: une étude comparative quantitative de trois entreprises privées du Burkina Faso. Journal Ouest-Africain des Sciences de Gestion, 1(1), 38-54.

Nassè, T. B. (2015). Internal equity as a factor of companies' economic profitability: a comparative study of three private companies in Burkina Faso through a qualitative approach. Saarbrucken, SA: Lamber Academic Publishing.

Odumeru, J. A. (2012). Diffusion of online recruiting technology in Nigeria. Online Journal of Social Sciences Research, 1(4), 104-114.

Omolawal, S. A., \& Onyeonoru, I. P. (2018). Influence of utilisation of information and communication technology for staff recruitment on the quality of staff recruited in South-West Nigeria. International Journal of Economy Business and Management, 6(2), 15-23.

Porter, M. E. (1996). What is a strategy? Harvard Business Review (November-December), 6178.

Rodrik D, Hausmann R, Velasco A. (2005). Growth Diagnostics. Copy at https://j.mp/2qQww9F

Rockart, J. F. (1979). Chief executives define their own data needs. Harvard Business Review, Vol. 3. (March-April)

Samwel, J. O., Omari, S., \& Szumbah, M. (2016). The influence of employees' recruitment on performance outcomes of family owned business in Tanzania case of Nyamagana and Ilemela Districts. African Journal of Business and Management, 2(3), 32-46.

Shenoy, V., \& Aithal, P. (2018). Literature review on primary organizational recruitment sources. International Journal of Management, Technology, and Social Sciences (IJMTS), 3(1), 37-58.

Sutano, E., \& Kurniawah, M. (2016). The impact of recruitment, employee performance on batik industry in Solo city, Indonesia. International Journal of Business and Society, 17(2), 375-390. https://doi.org/10.33736/ijbs.531.2016.

Teece, D. J. (2007). Explicating dynamic capabilities: the nature and micro-foundations of (sustainable) enterprise performance. Strategic Management Journal, 28(13),13191350 . 
Weber, M. (2018). Burkina Faso jobs diagnostic: Overview and suggestions for a jobs policy framework (English). Jobs Series; No. 15. Washington, D.C: World Bank Group.

Wickham, P.A. (2001) Strategic Entrepreneurship: A Decision-Making Approach to New Venture Creation and Management (2nd Edn.), Financial Times/Prentice Hall, London.

Williamson O. E. (1999) Public and private bureaucracies: a transaction cost economic perspective. Journal of Law Economics and Organization, 15(1), 306-347. 